\title{
Teaching Spanish in the United States in the digital age: Strategies and approaches on teaching Spanish in online and hybrid classes
}

\author{
Enseñar español en los Estados Unidos en la era digital: estrategias y \\ enfoques para enseñar español en línea y en clases híbridas
}

\author{
Liane She Honeycutt \\ Stanly Community College \\ Eli Sears \\ Portland State University
}

\begin{abstract}
Virtual technologies are omnipresent in everyday life and are becoming essential to either online, or hybrid classes. In higher education institutions in the United States, virtual platforms are increasingly used for teaching Spanish as a foreign language to students from varying backgrounds. As such, this article proposes an approach to teaching grammar in virtual spaces, that takes into account the communicative goals established in a given syllabus. The methods and strategies we propose offer an attractive language course that allows students to remotely learn and practice a language. As Spanish professors who teach beginning to intermediate level students, we will share our strategies for teaching grammar using concrete examples from our classes. We will also present data that show some measures of efficiency to teach Spanish grammar in a virtual setting.
\end{abstract}

Keywords: Foreign language; Communicative goals; Spanish grammar; Distance teaching and learning

\section{Resumen}

Las tecnologías virtuales son omnipresentes en la vida cotidiana y se han vuelto imprescindibles tanto en las clases en línea como en las semipresenciales. En las instituciones universitarias de Estados Unidos, las plataformas virtuales se utilizan cada vez más para español como lengua extranjera a estudiantes con diferentes perfiles. En este contexto, proponemos una aproximación a la enseñanza de la gramática en espacios virtuales que tenga en cuenta los objetivos comunicativos establecidos en el programa de estudios. Los métodos y estrategias que planteamos ofrecen un curso de lengua atractivo que permite a los estudiantes aprender y practicar un idioma a distancia. Como profesores de español de nivel inicial a intermedio de dos universidades distintas, compartiremos algunas estrategias para enseñar gramática utilizando ejemplos concretos de nuestras clases. Asimismo, presentaremos los datos que muestran algunas medidas eficaces para enseñar la gramática del español en un contexto virtual.

Palabras clave: Lengua extranjera; Aprendizaje comunicativo; Gramática española; Enseñanza y aprendizaje a distancia 


\section{DisTANCE EdUCATION: CONTEXT AND EFFECTS IN THE UNITED STATES}

Nowadays, online and hybrid teaching is becoming more and more present in American universities. This presents a challenge when teaching a language in a different setting than the traditional face-to-face one that for decades, professors have collectively developed a repertoire of methodologies and practices. In the last four years, positive results can be noted at Stanly Community College regarding how successful online and hybrid students have been.

Table 1. Increase in student success in online, hybrid courses at Stanly Community College

\begin{tabular}{ccc}
\hline $\begin{array}{c}\text { Academic year for online and hy- } \\
\text { brid course enrollment }\end{array}$ & $\begin{array}{c}\text { \% of students who failed with a } \\
\text { grade of } 69 / 100 \text { or less }\end{array}$ & $\begin{array}{c}\text { \% of students who passed with a } \\
\text { grade of } 70 / 100 \text { or more }\end{array}$ \\
\hline $2014-2015$ & 14,2 & 78,1 \\
$2015-2016$ & 14,6 & 79,1 \\
$2016-2017$ & 13,5 & 80,3 \\
$2017-2018$ & 13,9 & 80,3 \\
\hline
\end{tabular}

These results from Table 1 can be justified by the variety of technological tools available on campus. As a matter of fact, the Center for Teaching and Learning at Stanly Community College offers constant support to faculty when courses can be updated by implementing new tools. Therefore, it encourages faculty to improve the quality of content to be presented to students. In addition, having access to professional developments and conferences allow faculty to learn about new methods in order to design or redesign a clear and complete online course, and also make it accessible to any student who may have a disability. In 2019, Stanly Community College was ranked as the eleventh best community college in the United States for online courses (SR Education Group, 2019). Before we continue studying about the different methodologies and practices that positively impacted these good results for both virtual and hybrid courses, it is important to reaffirm the goal and perspective regarding teaching grammar, by giving more insights on students learning Spanish as a second language in the United States.

\section{TEACHING GRAMMAR IN A L2 CLASS IN THE UNITED STATES}

The way we, as instructors, define what grammar teaching means in second language courses is by ensuring that students improve the target language grammar rules so they can use it to interact and communicate better within the Spanish- 
speaking community. Therefore, grammar becomes a tool used for students to develop linguistic cultural and discursive abilities. In the last decades, this goal has involved a variety of pedagogical focuses, strategies and important questions regarding second and foreign language teaching. In the last decades, numerous publications and research were published - and still are - about second language acquisition (Doughty \& Long, 2003; Gass \& Mackey, 2013; Muñoz-Basols, Gironzetti \& Lacorte, 2019).

Although in this paper, the goal is not to advocate for one strategy over another, it is important to point out that the virtual spaces created for online classes offer several tools so the instructor can efficiently teach while using the pedagogical focuses and best practices from traditional face-to-face classes. In addition, we will show that thanks to virtual platforms and network accesses that are more and more present in universities and colleges, the quality of teaching in traditional class and access to authentic material and resources from Hispanic communities world-wide.

\section{STUDENTS OF SPANISH IN THE UNITED STATES}

There are a variety of students with different backgrounds in the United States. There are some who study Spanish as a foreign or second language, and others who study it as a heritage language. The motivations and interests in learning the language are numerous, but principally there is great interest in its practical application in a United States' workforce made up of many Spanish-speakers. Since the 80 s, a variety of courses were designed for a specific purpose in the academic environment and they keep increasing nowadays (Sánchez-López, 2018). One of this paper's authors teaches a distance education course for healthcare professionals through Pacific University in Oregon. The course recognizes that both linguistic and cultural competencies are essential in order to respond to the health needs of the Hispanic community in the United States (Hallick, n.d.).

As this article focuses on higher education teaching, there are specific considerations that need to be taken into account. Our students are adults and as such, the skills and the way they learn a second language is different than a younger individual. Adults who learn a second language have less processing memory than children and teenagers. Therefore, they depend more on their metalinguistic and pragmatic knowledge (Nikolov \& Djigunović, 2006). Learning a second language as adults requires more than being surrounded by speakers and using it in social events. 
The majority of students in the United States learn Spanish as a foreign language as they are not immersed in a community where Spanish is the main language. Therefore, there is a need to enjoy each minute of class amongst professors who teach languages in the United States in order to provide authentic communicative and cultural experiences. As a result, learning grammar by paying further attention and reflecting to the form is reduced within the classroom and students will focus on it more in homework outside of class. As it is discussed in this article, the technology used in online and hybrid classes have a lot to provide for studying grammar of a foreign language in the United States. In addition, some traditional students have a full-time job or have family obligations while they study. Nowadays, technology shows that a large panorama of students has access to online classes such as Spanish ones, as it gives them the option to study remotely, in order for them to successfully complete their studies and graduate without having to physically come to campus.

\section{STRATEGIES TO TEACH A LANGUAGE ONLINE}

Very often, students are afraid to choose an online class as they do not always feel prepared or autonomous enough to study on their own. They fear that professors will leave them alone in front of their screens. Although as professors have a role to support them and remind them that we are always available for them through email, Skype, or phone, they remain too shy to ask us for help or share their doubts with us. Therefore, one way to help them overcome this fear is to plan frequent synchronous classes, or live online sessions. These synchronous sessions indeed allow more interactions not only between the students, but also with the professor. Some tools such as Zoom, Google Hangout in Gmail, Skype and Adobe Connect give the option to organize online meetings and share our webcam, screen with the content we would like to share such as virtual whiteboards. This allow us to write down important concepts from a given lesson as if we were in a traditional classroom. In addition, some virtual groups can be created in case instructors want to plan an activity in group or in pairs. In order to practice grammar with communicative activities, synchronous online sessions have been improving significantly and can also be recorded and shared.

In order to be successful and to ensure that students pay attention and stay in the course, it is important that synchronous classes are planned ahead of time. For instance, every two weeks before an exam, a live synchronous session can help students study and review the content, and they will also have the opportunity to ask questions live. In Stanly Community College's Spanish classes, this 
methodology became efficient through Zoom, and students are aware that by attending them, they can get tutoring by their professor and have the opportunity to practice what they have studied. It is paramount to nonetheless remember that online students will not have the same availability as the professor or their classmates. It has been noticed that the majority of those students have a full-time job and/or a family to take care of. Therefore, their schedule does not always work with those synchronous sessions.

\section{USING ASYNCHRONOUS VIDEOS FOR TUTORING AND HOMEWORK}

Another solution is to create asynchronous videos to add on to the teaching content, as they have the benefit of being included on a virtual platform so students can watch them as much as they want, anytime they want. Therefore, synchronous classes can be recorded and watched anytime.

However, this also involves another important factor, which is the duration of the video. For a synchronous class, ideally a video should not last more than fifty minutes so that students can be encouraged to watch step by step, pause it, while taking notes and asking questions to the professor through email, Skype, or any other communication means. In that case, they must be warned that the video is long because it is the equivalent of a class session recording.

However, implementing short videos is also a must for online students. It is important to keep in mind that a video tutorial cannot be too long, therefore we tend to limit them to less than fifteen minutes as much as possible. As a matter of fact, it has been observed by Berg et al. (2014) that students' attention can vary between ten and fifteen minutes each time, which not only applies to an online setting but also in a traditional classroom. In the United States, there are several platforms with videos that are already recorded by other colleagues from other institutions such as Khan, Cosmolearning and Spanish for Dummies. On those platforms, it has been noted that some videos for Spanish are sometimes extremely long or do not have any type of visual interaction. This is what we should avoid when we create our own materials.

The duration of the video is usually what students see first before even playing it. This is mostly due to their busy schedules, therefore the videos that we provide them must be adjusted to talk about only one particular theme, such as the differences between saber and conocer for instance. Through this strategy, we expect better results as students are more likely to watch short videos rather than one 
hour and a half long lectures. They will learn and get the most of short and concise videos than longer ones. In this case, "less is more".

One program that is often used in Stanly Community College's online courses is Screen Cast-O-Matic, which allows to share both screen and webcam. This is of course not the only program. For instance, professors from Portland State University have access to Kaltura MediaSpace, which also allows professors to record both screen and webcam simultaneously. In these short tutorials, a PowerPoint or Google Slides presentation is always shared on the screen and the webcam is always on, so students can have some sort of contact and interaction with us and see that we are the authors of these videos. Screen Cast-O-Matic can be used for free for up to fifteen minutes. It turns out that this is the perfect duration, as videos have to remain concise and only talk about one grammar concept. Once the recording is done, the video can be downloaded in an MP4 format or be published directly on our YouTube channel. The advantage of using YouTube is that captions and subtitles can be added to the video, so that the video can be accessible to any student with disability. In addition, in this same presentation, it is recommended to avoid light or bright colors so the content in itself can be visible by all students, and for any screen resolution.

ED Puzzle is another potential platform from the United States that already counts with certain video tutorials available for both students and professors. The advantage of ED Puzzle is that it is possible for us to download our own video and there is a feature that keeps track of which student has logged in and watched it. This feature is accessible to the professor so they have full control over it, which turns out to be extremely convenient.

Asynchronous videos can also be used as homework in order to compensate for the lack of visual interaction between students and their instructor. Many of today's education platforms, such as FlipGrid and GoReact allow students to record their own videos which can be used to evaluate their oral production and comprehension. This allows an extra level of peer interaction by interacting visually and auditorily in a more authentic language setting. In face-to-face interactions, our tone and gestures give a subtext to our audible syntax that serves as a marker to bolster or modify meaning. Additionally, an instructor can use these tools to give more direct feedback in a natural face-to-face simulation. Lastly, bringing faceto-face interaction to the online classroom, even asynchronously, helps build a sense of community as the students and their instructor are not hiding behind a screen and behind their written text. Aside from these advantages in online courses, 
it is worth mentioning that homework assignments that use vide can be an added advantage to traditional classes as they allow students time to prepare for an oral task at their own pace. This is an easy way to help reduce the stress and anxiety that can sometimes overcome students when they have to speak on the spot in the classroom. Students can record their videos while they are alone, and they have the option of starting again if they are not satisfied with how their first attempt came out.

The rapid expansion of digital storage space is beginning to coincide more and more with new, digital education technologies. Not only has this shown useful for distance learning but also for creating more communicative opportunities for students in traditional classes. Nowadays, homework does not have to be limited to written exercises and individual work and study. Communicative video, audio, or text-based assignments can be given in order for students to communicate even when they are not in class. These types of assignments increase the linguistic and social interactions between students and highlight the role language has as a tool for expression and community interaction, not only a focus that promotes learning structures to pass an exam. Similarly, it changes the way in which educators interact with students. Video and audio feedback can replace written feedback on a piece of paper where an instructor can be more detailed and animated in their feedback. Again, this also increases the amount of personalized face-to-face contact that instructors have with their students.

\section{The USE OF LEARNING MANAGEMENT SySTEMS (LMS)}

Learning Management Systems used by universities are becoming better and better integrated with the omnipresent mega platforms like Google and Microsoft. As such, it has become very easy to share materials with our students. Documents, presentations, video tutorials, study materials, and quizzes are easily insertable and shared with students directly through the school's LMS. Quizzes made directly in the LMS or in more accessible formats like Google Docs can be corrected automatically or manually and, if desired, instructors can provide specific feedback to each student. Students can check their comprehension immediately and, in turn, instructors receive useful data about the results, for example, the most frequently missed questions and class averages. 


\section{A PRACTICAL EXAMPLE}

Here we share an example of how online tools were used to fortify instruction in a traditional classroom. In an intermediate, third year Spanish course at Portland State University in the fall of 2018, online tools were used during an extended unit on the subjunctive mood-undoubtedly a difficult structure for English speaking students to learn because of its syntactic and semantic complexity. In this course the subjunctive was presented in a pretty traditional way through the textbook Repase y escriba (Dominicis, 2014). The book divides the subjunctive into three chapters. Each chapter looks at the subjunctive through a syntactic and semantic lens based on the three types of dependent clauses the subjunctive is regularly found in; noun, relative, and adverbial clauses. In this particular course, an online segment was added at the end of all three units to review and practice the subjunctive. The review consisted of three different video grammar classes approximately ten minutes in length, as well as several exercises, quizzes, and communicative tasks the students were given at home through the University's online LMS, D2L, and Google Forms.

In contrast to previous editions of this course, this was the only major change that was implemented on the weeks covering the subjunctive. At the end of the semester, results from the final exam and written essays from students who completed the online review were compared with an identical exam and essay assignment from previous semesters wherein the students did not have access to the online review, exercises and quizzes, but were left to only written review materials and written exercises with similar content. When comparing and examining the use of the indicative and subjunctive from these two groups of students in their exams and compositions, the results indicated that the pedagogical addition using online materials translated to an improvement in the student's understanding and production of verbal mood.

\section{METHODOLOGY AND RESULTS}

Twenty-four students actively completed the online review and activities. Three students from the course who did not actively complete the online review and activities are grouped with students from previous courses who did not participate in the online review and activities. Together, they totaled fifty-three students. The average of correct usage of mood on the final exam increased from $82 \%$ to $88 \%$ in favor of the twenty-four students who completed the online review and activities (Figure 1). Additionally, the analysis of compositions from these same two groups 
Figure 1. Subjunctive learning outcomes at Portland State University

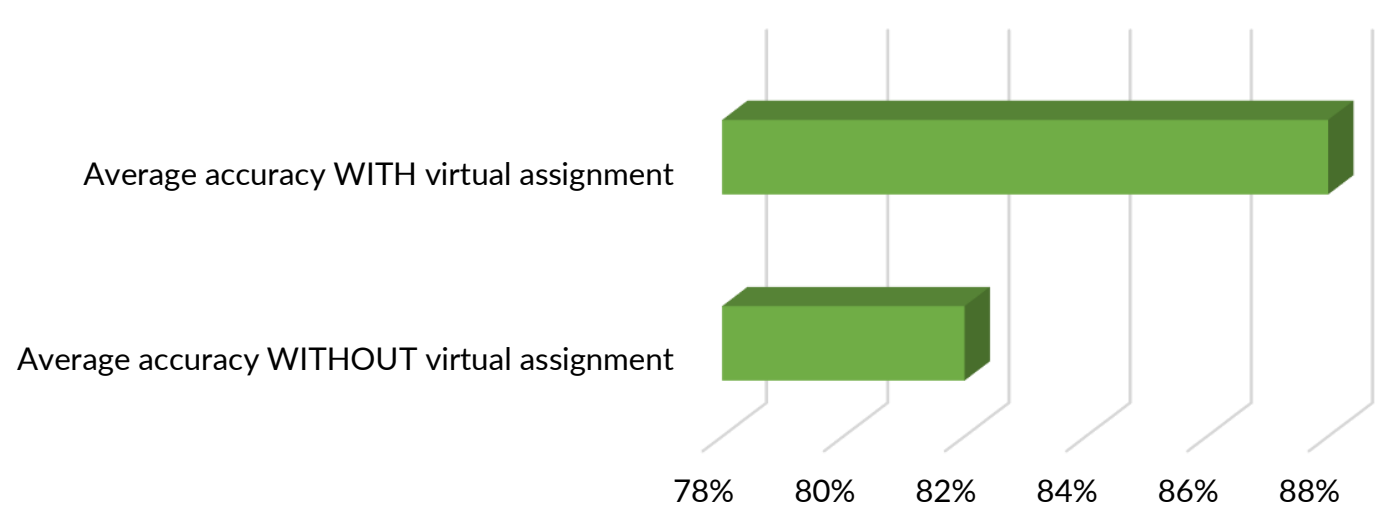

\% of correct mood-choice answers on exam

of students showed that the same twenty-four students had an average of 1.5 fewer mood selection errors in their final compositions (Figure 2). These results seem to complement each other and indicate improvement in student's understanding of mood selection as the rest of the instruction around the subjunctive was left unmodified from previous courses. To produce this data, mood selection errors were counted on the exams and compositions from a third-year Spanish course from the Fall, 2018 semester. These errors were grouped into one data set which shows the outcomes of students who participated fully in the added, online assignment. Additionally, a separate data set was created by counting student mood-selection errors from two previous courses who took the same exam and wrote the same composition assignment. The only factor considered when deciding what constituted an error on the exam and compositions was mood selection. Because the unit and textbook focus on when to use each mood, errors in areas such as conjugation,

Figure 2. Subjunctive and indicative errors in compositions at Portland State University

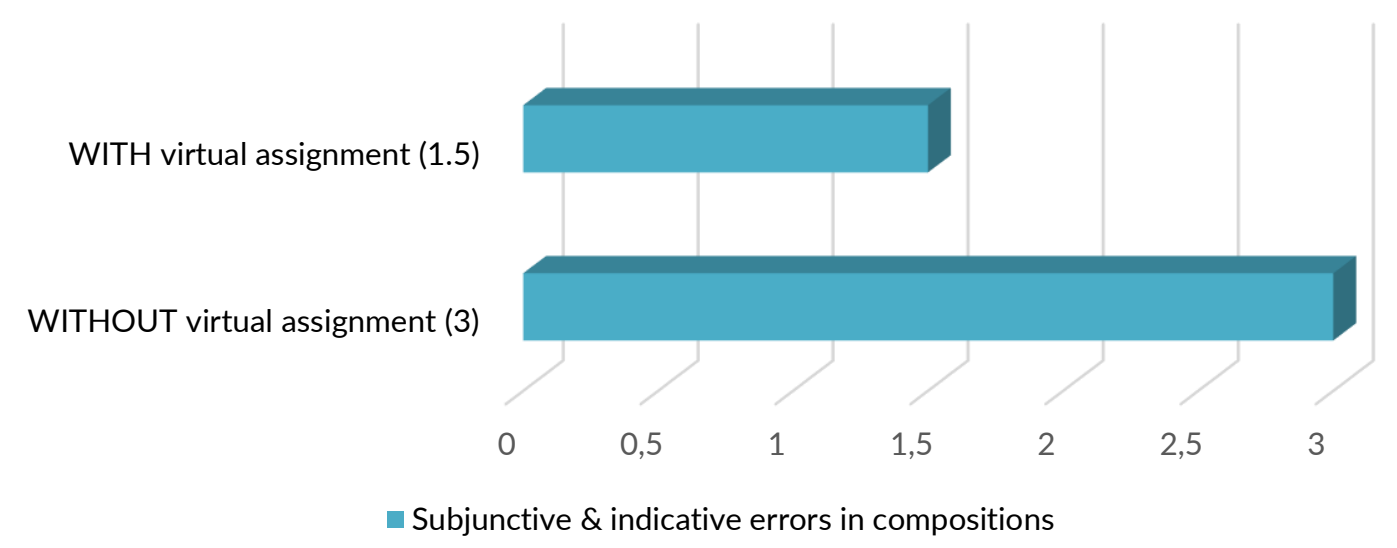


tense, and orthography were not counted as mood selection errors. The average error in mood-selection per composition was then calculated from each data set and, subsequently, compared to see which group showed overall, better performance outcomes in mood selection. The analyzed outcomes from the exam reflect the student's ability to interpret syntactic and semantic elements that influence mood selection, at least in the short term. Likewise, the analyzed outcomes from student compositions measure the progress students made when moving from a theoretical and interpretive analysis of mood selection to practical, communicative usage.

To support the efficiency of teaching a foreign language online, data was collected from beginning and intermediate classes at Stanly Community College (Figures 3 and 4). Every semester, student learning outcomes results are measured in each online section, for the instructor to compare with previous semesters and make potential improvements to the course. For the Elementary Spanish course, the student learning outcomes used to collect those results were the following:

1. Compose simple sentences, in the present tense, using appropriate verb forms, gender and number agreement and syntax by scoring a $70 \%$ or higher on the writing section of the final exam.

2. Respond orally to questions on everyday topics by scoring a $70 \%$ or higher on the response section of five oral chapter exams.

3. Interpret basic information and vocabulary in a variety of basic, personal and social contexts at the Beginner mid-level as described by the American Council of the Teaching of Foreign Language (ACTFL); and be able to answer the questions with a complete sentence using the present tense, by scoring a $70 \%$ or higher in the listening section of the final exam.

Previous to fall semester 2017, students did not yet have access to virtual tools in language classrooms. Between fall semester 2017 and fall semester 2018, online students began having access to more virtual tools with which they could interact orally, auditively, and in written form. Software we have discussed such as Zoom, Screen-Cast-O-Matic and Adobe Connect became available for instructors and students. This interactive use of technology has benefited students with the same quality of teaching students would get in a traditional classroom. Therefore, that can in part justify the growing curve that has been observed in specific language skills. 
Figure 3. Stanly Community College - Elementary Spanish

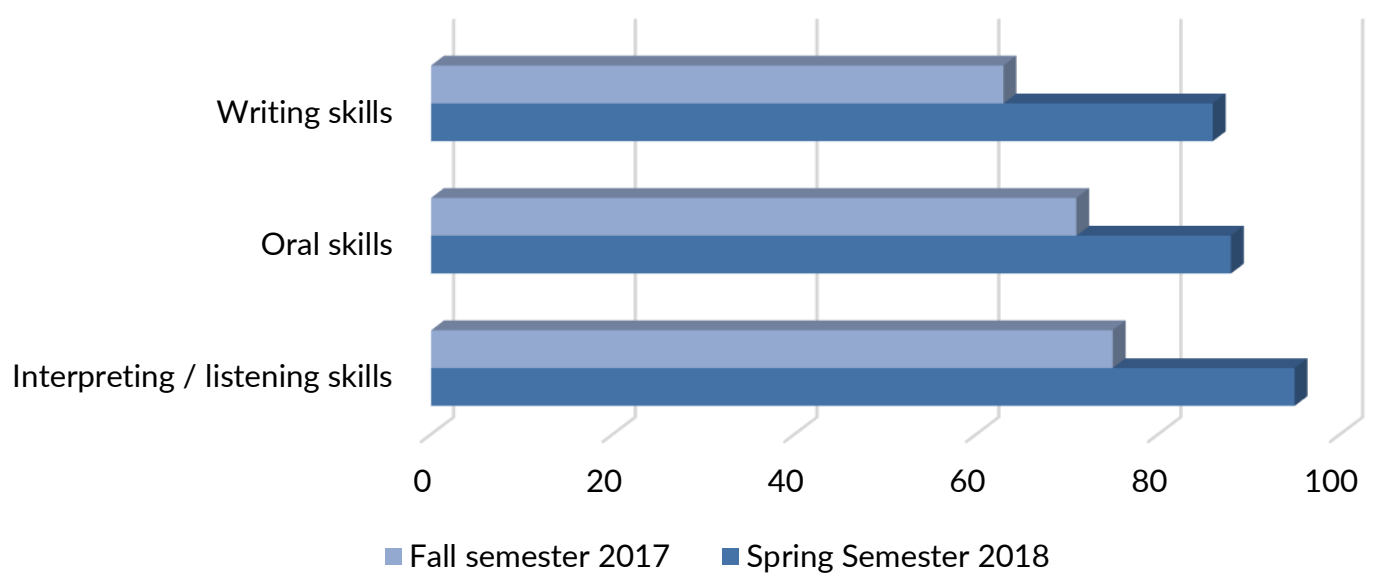

Nevertheless, one limitation in presenting the data is that the percentage is calculated by the number of students in each class. This number can vary every semester depending on the demand. It is also important to note that every semester, students who register at the beginning level have a diverse profile. Some come with no previous knowledge of Spanish while others may already have some knowledge of the language from high school or from growing up in a bilingual climate.

Figure 4. Stanly Community College - Intermediate Spanish Results

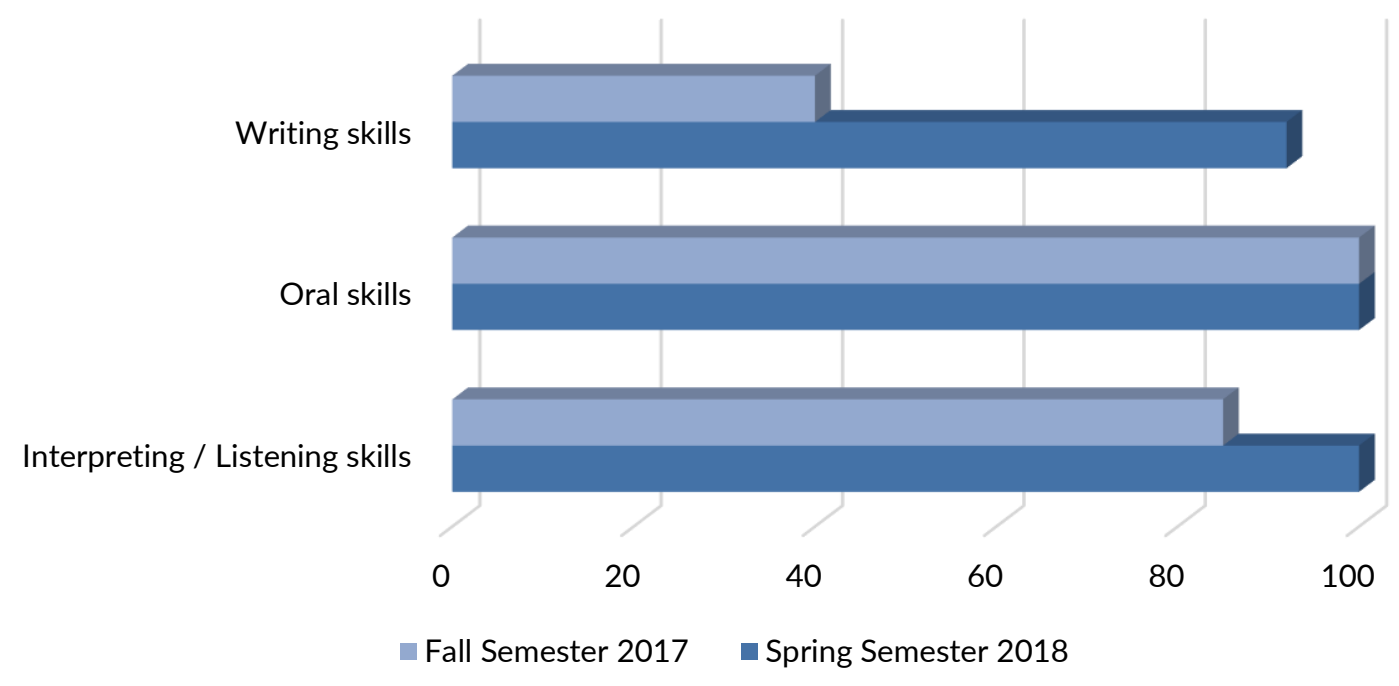


For the intermediate Spanish course, the student learning outcomes that were measured were the following:

- Communicate thoughts, ideas, and opinions orally, at the Intermediate midlevel as described by the American Council of the Teaching of Foreign Language (ACTFL) by scoring a $70 \%$ or higher on the oral final exam.

- Communicate thoughts, ideas, and opinions in writing, at the Intermediate mid-level as described by the American Council of the Teaching of Foreign Language (ACTFL) by scoring a $70 \%$ or higher on the writing section of the final exam.

- Interpret simple, sentence length speech in a variety of basic personal and social contexts at the Intermediate mid-level as described by the American Council of the Teaching of Foreign Language (ACTFL) by scoring a $70 \%$ or higher on the listening section of the final exam.

Regarding the results that were obtained in the online intermediate class, we had to take into consideration that the majority was already familiar with the online format, as they had previously taken the elementary online course with the same instructor. This could potentially justify the reason for which all students from the fall 2017 and spring 2018 semesters had above average results in their oral skills, given that oral evaluations previously had a similar format. However, an increased curve between fall 2017 and spring 2018 was also observed in student's writing, interpreting, and listening skills after implementing more virtual and interactive tools in the class. As a result, we are able to establish that even though a class is taught online, it is always paramount to show that a professor establishes social presence and makes oneself available for students. The simple reality of being able to show one's face through video creates more personal contact between students and their instructor. This leads to greater confidence between them, and the student's autonomy and interest begin to grow.

\section{CONCLUSIONS}

We have established that virtual courses offer new opportunities to explore how instructors teach a second language and how we create a communicative community. The quality of education that we offer to students in online, hybrid, and faceto-face classes can benefit from technological advances by creating a more interactive course for students and instructors alike. This also encourages more diverse student profiles as more and more students have access to learning a language, 
notwithstanding their location and availability. Courses with more access and variety can, under certain conditions, lead to more successful learning outcomes, especially regarding grammatical structures. Distance learning courses that take place online ease the access of collaboration between students and instructors in across wider geological locations They also make room for the possibility of interacting with diverse cultures and communities.

Kramsch and Thorne (2002) have proposed that communication does not just consist of transmitting information and negotiating meaning, but of the necessity humans have to identify and belong to a community of discursive practice. The obvious solution, whenever possible, is to study and live abroad or in a community where the language learned is the dominant social language. There is no shortage of language students who want to go abroad but who also lack the opportunity, whether the reason be economic or something else. The Internet offers virtual spaces where social connections between languages and cultures are now a reality. Not only do they allow social interactions between two or more people, but they also allow wider access to authentic cultural artifacts, such as cinema. In both Kaiser (2011), and Kaiser \& Shibahara (2014), it is argued that access to foreign films allows students to focus on spoken language, behaviors and values in a community of language speakers, and the meaning that is produced in both the spoken language and filmic text of cinema. If our goal is to form students who are better prepared to interact in Spanish speaking communities, it is essential that future studies and pedagogical practice delve deeper into these possibilities.

\section{REFERENCES}

Berg, R., Brand, A., Grant, J., Kirk, J., \& Zimmermann, T. (2014). Leveraging recorded mini-lectures to increase student learning. Online Classroom, 14(2), 5-8.

Dominicis, M. C. (2014). Repase y escriba: Curso avanzado de gramática y composición. Hoboken, NJ: Wiley.

Doughty, C., \& Long, M. H. (2003). The handbook of second language acquisition. Malden, MA: Blackwell Pub.

Gass, S. M., \& Mackey, A. (Eds.). (2013). The Routledge handbook of second language acquisition. Routledge.

Hallick, L. M. (n.d.). Healthcare Spanish Program. https://www.pacificu.edu/colleges/collegehealth-professions/interprofessional-programs/courses-offered/healthcare-spanish-program

Kaiser, M. (2011). New approaches to exploiting film in the foreign language classroom. L2 Journal, 3(2), 232-249.

Kaiser, M., \& Shibahara, C. (2014). Film as source material in advanced foreign language classes. L2 Journal, 6(1), 1-13. 
Kramsch, C., \& Thorne, S. L. (2002). Foreign language learning as global communicative practice. In D. Block and D. Cameron (Eds.), Globalization and Language Teaching (pp. 83100). London: Routledge.

Muñoz-Basols, J., Gironzetti, Elisa, \& Lacorte, Manel. (2019). The Routledge handbook of Spanish language teaching: Metodologías, contextos y recursos para la enseñanza del español L2. Abingdon, Oxon; New York, NY: Routledge.

Nikolov, M., \& Djigunović, J. M. (2006). Recent research on age, second language acquisition, and early foreign language learning. Annual review of applied linguistics, 26, 234-260.

Sánchez-López, L. (2018). Español para profesiones. In J. Muñoz-Basols, E. Gironzetti, \& M. Lacorte (Eds.), The Routledge Handbook of Spanish Language Teaching (pp. 520-532). London, England: Routledge.

SR Education Group. 2019 Best Online Community Colleges. https://www.guidetoonlineschools.com/best-online-community-colleges

\section{LIANE SHE HONEYCUTT}

She is the Spanish and French Instructor, and Global Education Liaison at Stanly Community College. She received her MA in Spanish Arts at UNC Charlotte, where she is currently completing her doctoral degree in Educational Leadership. Liane's academic interests include linguistics, distance teaching and learning, and Spanish and French second language acquisition.

lhoneycutt1167@stanly.edu https://orcid.org/0000-0001-5274-1212

\section{ELI SEARS}

He is a senior adjunct instructor of Spanish at Portland State University, Portland Community College, and an adjunct instructor of Healthcare Spanish at Pacific University. He received his BA and MA in Spanish at Portland State University where he also works as an adjunct Spanish instructor. Eli's academic interests include linguistics, lexicography, dialectology, and Spanish second language acquisition.

esears@pacificu.edu https://orcid.org/0000-0002-6917-301X

Honeycutt, L. S. \& Sears, E. (2020). Teaching Spanish in the United States in the digital age: Strategies and approaches on teaching Spanish in online and hybrid classes. Bellaterra Journal of Teaching \& Learning Language \& Literature, 13(2), e838. https://doi.org/10.5565/rev/jt13.838

Rebut / Recibido / Received / Reçu: 31-10-2019

Acceptat / Aceptado / Accepted / Accepté: 14-06-2020 